\title{
PENGARUH KEPUASAN KONSUMEN TERHADAP LOYALITAS MEREK PRODUK KRIM PEMUTIH POND'S PADA MAHASISWI MANAJEMEN FAKULTAS EKONOMI UNIVERSITAS NEGERI SURABAYA
}

\author{
*(Luluk Nur Azizah \\ Fakultas Ekonomi \\ Universitas Islam Lamongan,
}

\begin{abstract}
ABSTRAK
Pada saat ini, persaingan antara produsen kosmetik di Indonesia semakin ketat. Para produsen kosmetik di Indonesia berkompetisi untuk menciptakan produk pelembab wajah yang berkualitas dan sesuai dengan para wanita. Produk krim Pemutih Merek Pond's merupakan produk pelembab wajah yang sudah dikenal oleh banyak masyarakat. Perusahaan tidak hanya mengginginkan produk krim Pemutih Merek Pond's dikanal saja tetapi perusahaan menggingikan para konsumenya terpuaskan dan pada akhirnya konsumen akan loyal terhadap produk pemutih merek Pond's. Penelitian ini bertujuan untuk mengetahui seberapa besar Pengaruh Kepuasan Konsumen terhadap loyalitas merek pada produk Pond's. Responden yang terlibat dalam penelitian ini sebanyak 100 mahasiswi Manajemen Fakultas Ekonomi. Metode yang digunakan adalah non probability sampling, yaitu Purposive sampling. Pengumpulan data dilakukan dengan menyebar angket. Metode analisis data dilakukan dengan regresi linier sederhana menggunakan software SPSS versi 16. Dari hasil penelitian ini, dapat diketahui bahwa variabel $X$ yaitu kepuasan konsumen berpengaruh positif dan signifikan terhadap variabel $Y$ yaitu loyalitas merek pada produk Pond's. Untuk nilai adjusted $R$ Square yang diperoleh sebesar 0,348 yang artinya ada pengaruh kepuasan konsumen terhadap loyalitas merek sebesar $34,8 \%$, sedangkan sisanya 65,2\% dipengaruhi oleh variabel lain yang tidak digunakan dalam penelitian ini.
\end{abstract}

\section{Kata kunci : Kepuasan Konsumen, Loyalitas Merek}

\section{PENDAHULUAN}

Dunia pemasaran yang semakin kompetitif menuntut perusahaan untuk memiliki keunggulan a saing. Untuk dapat tetap eksis di dalam proses produksi dan kualitas perusahan tetap terjaga perusahaan dituntut untuk.semakin bekerja keras, pintar, dan .kreatif. Di sisi lain konsumen dihadapkan pada berbagai macam pilihan produk. Membuat produk yang bermutu dan digemari konsumen merupakan tantangan bagi perusahaan.

Dalam kondisi semakin meningkatnya persaingan antara produkproduk sejenis, maka perusahaan yang satu dengan yang lain saling bersaing merebutkan konsumen. Perusahaan yang mampu menciptakan dan mempertahankan pelangganlah yang akan sukses dalam persaingan. Setiap perusahaan berusaha untuk memahami perilaku konsumen pada pasar sasaran untuk kelangsungan hidup perusahaan tersebut. Perilaku konsumen yang ada tersebut akan mempengaruhi cara konsumen dalam melihat atau memandang suatu produk.

Konsumen dalam memilih suatu merek produk akan melalui tahap percobaan terlebih dahulu, pada tahap ini seringkali konsumen akan mencoba 
berbagai merek yang berbeda. Jika dirasakan bahwa merek tersebut cocok dan memenuhi apa yang diharapkan dan terjadi suatu titik kepuasan dalam mengkonsumsi merek tersebut dari produk sejenis maka konsumen akan terus mencari merek tersebut.

$$
\text { Philip Kotler (2007:177) }
$$

menyatakan bahwa "Kepuasan konsumen adalah perasaan senang atau kecewa seseorang yang muncul setelah membandingkan antara persepsi/kesannya terhadap kinerja berada di bawah harapan, pelanggan tidak puas, jika kinerja melebihi harapan, pelanggan amat puas dan senang".

Krim Pemutih pada Merek Pond's merupakan salah satu produk yang diciptakan oleh unilever untuk mengatasi masalah-masalah yang dihadapi oleh mahasiswi karena sebab diatas tadi.

Krim Pemutih pada Merek Pond's diperkaya dengan VAO- $\mathrm{B}^{3}$ complex dan pelindung ganda dari sinar matahari, krim pelembab ini tahu dimana kulit anda paling membutuhkan pertolongan ekstra. Hasil yang akan anda dapatkan yaitu kulit tampak lebih putih, bersih, bersinar, dan juga terlindung dari sinar matahari.(www.vivawoman.net)

Produk yang bisa memuaskan adalah produk yang dapat memberikan sesuatu yang dicari oleh konsumen sampai pada tingkat cukup. Dalam konteks teori perilaku konsumen, kepuasan lebih banyak didefinisikan dari perspektif pengalaman konsumen setelah mengkonsumsi atau menggunakan suatu produk atau jasa. Jika kinerja berada di bawah harapan, konsumen tidak puas. Jika kinerja melebihi harapan, konsumen amat puas atau senang.

Sehubungan dengan hal tersebut, maka komponen dari variabel kepuasan konsumen yang digunakan dalam penelitian ini adalah sebagai berikut: Attributes related to the product yang mempunyai sub indikator Value-price relationship, Product quality, dan Product benefit
Kotler \& Keller (2007: 177) mendefinisikan bahwa kepuasan adalah perasaan senang atau kecewa seseorang yang muncul setelah membandingkan kinerja (hasil) produk yang dipikirkan terhadap kinerja (atau hasil) yang diharapkan. Jika kinerja berada dibawah harapan, pelangan tidak puas. Jika kinerja melebihi harapan pelanggan amat puas atau senang.

Secara umum dapat dikatakan bahwa kepuasan adalah semacam langkah perbandingan antara pengalaman dengan hasil evaluasi, dapat menghasilkan sesuatu yang nyaman secara rohani, bukan hanya nyaman karena dibayangkan atau diharapkan. Puas atau tidak puas bukan merupakan emosi melainkan sesuatu hasil evaluasi dari emosi. konsumen yang senang dan puas cenderung akan berperilaku positif. Mereka akan membeli kembali produk tersebut.

Kepuasan merupakan fungsi dari kesan kinerja dan harapan. Jika kinerja berada di bawah harapan, pelanggan puas. Jika kinerja melebihi harapan, pelanggan amat puas atau senang. Kepuasan tinggi atau kesenangan menciptakan kelekatan emosional terhadap merek, bukan hanya preferensi rasional. Hasilnya adalah loyalitas konsumen terhadap merek tersebut tinggi. Kepuasan tidak akan pernah berhenti pada satu titik. Ia bergerak dinamis mengikuti tingkat kualitas produk dengan harapan-harapan yang berkembang di benak konsumen

Sumarwan

(2002:326) mendefinisikan "Loyalitas merek diartikan sebagai sikap positif seorang konsumen terhadap suatu merek, konsumen memiliki keinginan kuat untuk membeli ulang merek yang sama pada saat sekarang maupun masa datang”. Seorang pelanggan yang sangat loyal kepada suatu merek tidak akan dengan mudah berpindah ke merek lain, apapun yang terjadi dengan merek tersebut.Berdasarkan hal ini dapat dirumuskan hipotesis bahwa : 
Ha : Ada pengaruh kepuasan konsumen terhadap loyalitas merek produk krim pemutih Pond's

Ho : Tidak ada pengaruh kepuasan konsumen terhadap loyalitas merek produk krim pemutih Pond's

\section{TUJUAN PENELITIAN}

Fokus utama dari penelitian ini adalah "Untuk mengetahui kepuasan konsumen yang terdiri dari Value-price relationship, Product quality, dan Product benefit berpengaruh terhadap loyalitas merek pada produk krim pemutih Pond's"

\section{METODE PENELITIAN}

Penelitian ini dimaksudkan untuk mengetahui pengaruh kepuasan konsumen terhadap loyalitas merek produk krim pemutih pond's. Atribut kepuasan konsumen yang digunakan dalam penelitian ini adalah Attributes related to the product.yang terdiri dari sub indicator Value-price relationship, Product quality, dan Product benefit

Populasi penelitian ini adalah mahasiswi Manajemen Fakultas Ekonomi Universitas Negeri Surabaya yang menggunakan produk krim pemutih Pond's minimal 2 kali pembelian., Penarikan sampel nonprobabilitas dalam penelitian ini dilakukan dengan cara purposive sampling. Sugiyono (2008:85) mendefinisikan Purposive sampling adalah teknik penentuan sampel dengan pertimbangan tertentu, yaitu dengan cara pengambilan sampel secara sengaja sesuai dengan persyaratan sampel yang diperlukan. itu dikerena peneliti tidak dapat mengetahui dengan pasti orang yang benar- benar menggunakan produk yang diteliti. Data untuk dianalisis adalah data primer dan data sekunder, yang diperoleh dari 100 orang sample (responden)

Alat yang digunakan untuk mengumpulkan data adalah angket dimana alternatif jawaban dari pertanyaan telah disediakan. Sedangkan untuk pengukurannya menggunakan skala likert. Menurut Sugiono (2006 : 107) "Skala likert adalah skala yang digunakan untuk mengukur sikap, pendapat, dan persepsi seseorang atau sekelompok orang tentang fenomena sosial".

Variabel kepuasan konsumen yang digunakan peneliti adalah Attributes related to the product yang mempunyai indikator Value-price relationship, Product quality, dan Product benefit yang didapatkan dari krim pemutih Pond's

Konstruk Loyalitas merek diukur dengan menggunakan ciri-ciri dari konsumen yang loyal yaitu, Memiliki komitmen pada merek tersebut, berani membayar lebih pada merek tersebut bila dibandingkan dengan merek yang lain, akan merekomendasikan merek tersebut pada orang lain, dalam melakukan pembelian kembali produk tersebut tidak melakukan pertimbangan, selalu mengikuti informasi yang berkaitan merek tersebut, mereka dapat menjadi semacam juru bicara dari merek tersebut dan mereka selalu mengembangkan hubungan dengan merek tersebut.

\section{HASIL ANALISIS DATA REGRESI LINIER SEDERHANA}

Berdasar perhitungan regresi linier sederhana antara Kepuasan konsumen terhadap Loyalitas merek dengan menggunakan program SPSS, diperoleh hasil sebagai berikut 
Tabel 4.21

Uji Model Regresi Linier Sederhan

Coefficients $^{\mathrm{a}}$

\begin{tabular}{|c|c|c|c|c|c|c|c|c|c|c|}
\hline \multirow[b]{2}{*}{ Model } & \multicolumn{2}{|c|}{$\begin{array}{c}\text { Unstandardized } \\
\text { Coefficients }\end{array}$} & \multirow{2}{*}{\begin{tabular}{|c}
$\begin{array}{c}\text { Standardize } \\
\mathrm{d} \\
\text { Coefficient } \\
\mathrm{s}\end{array}$ \\
Beta \\
\end{tabular}} & \multirow[b]{2}{*}{$\mathrm{T}$} & \multirow[b]{2}{*}{ Sig. } & \multicolumn{3}{|c|}{ Correlations } & \multicolumn{2}{|c|}{$\begin{array}{c}\text { Collinearity } \\
\text { Statistics }\end{array}$} \\
\hline & B & $\begin{array}{l}\text { Std. } \\
\text { Error }\end{array}$ & & & & $\begin{array}{l}\text { Zero- } \\
\text { order }\end{array}$ & $\begin{array}{c}\text { Part } \\
\text { ial }\end{array}$ & Part & $\begin{array}{c}\text { Toleran } \\
\text { ce }\end{array}$ & VIF \\
\hline $\begin{array}{ll}1 & \text { (Constan } \\
\text { t) }\end{array}$ & 11.546 & 1.979 & & 2.452 & .016 & & & & & \\
\hline$X$ & .270 & .040 & .727 & $\begin{array}{r}10.49 \\
5\end{array}$ & .000 & .727 & .727 & .727 & 1.000 & 1.000 \\
\hline
\end{tabular}

a. Dependent Variable:

$\mathrm{Y}$

Tabel 4.22

Koefisien regresi variabel X (Kepuasan Konsumen) dan variabel Y (Loyalitas merek )

\begin{tabular}{|c|c|c|c|}
\hline \multicolumn{2}{|c|}{ Variabel } & \multirow{2}{*}{$\begin{array}{c}\text { Koefisien } \\
\text { Regresi }\end{array}$} & \multirow{2}{*}{ Constant } \\
\hline Variabel Terikat & Variabel Bebas & & \\
\hline Loyalitas merek (Y) & $\begin{array}{c}\text { Kepuasan Konsumen } \\
(\mathbf{X})\end{array}$ & 0,270 & 11.546 \\
\hline
\end{tabular}

Sumber : Data primer yang diolah (2011)

Dari tabel diatas, maka dapat dilihat bahwa nilai a (konstanta) untuk persamaan regresi linier sederhana adalah 11.546 sedangkan nilai b (koefisien regresi) untuk persamaan regresi linier sederhana adalah 0,270. Selanjutnya setelah harga a dan b ditemukan, maka persamaan regresi linier sederhana dari nilai kepuasan konsumen dan loyalitas merek adalah sebagai berikut:

$\mathrm{Y}=\mathrm{a}+\mathrm{bX}+\mathrm{e}$

$Y=11.546+0,270 X+e$

Berdasar pada persamaan regresi diatas dapat dijelaskan sebagai berikut:

a. Nilai konstanta sebesar 11.546 menunjukkan yaitu variabel kepuasan konsumen (X), diasumsikan sama dengan nol, maka diprediksikan Loyalitas Merek (Y) adalah sebesar 11.546. Maknanya, jika terjadi kepuasan pada konsumen terhadap produk Pond's , maka loyalitas merek mahasiswi Fakultas Ekonomi Jurusan Manajemen akan naik sebesar 11.546.

b. Nilai koefisien regresi variabel kepuasan konsumen (X) adalah sebesar 0,270 artinya jika $\mathrm{X}$ berubah satu satuan maka variabel loyalitas merek (Y) akan berubah dengan koefisien regresi sebesar 0,270

Selanjutnya uji $\mathrm{R}^{2}$ digunakan untuk hubungan atau besarnya pengaruh yang ditimbulkan oleh variabel bebas (X) terhadap variabel terikat $(\mathrm{Y})$. $\mathrm{Uji} \quad \mathrm{R}^{2}$ diperoleh dari hasil analisis regresi pada tabel model summary dibawah ini. 
Tabel 4.23

Model Summary

Model Summary ${ }^{\text {b }}$

\begin{tabular}{|l|c|r|r|r|r|}
\hline Model & $\mathrm{R}$ & \multicolumn{1}{|c|}{ R Square } & \multicolumn{1}{c|}{$\begin{array}{c}\text { Adjusted R } \\
\text { Square }\end{array}$} & $\begin{array}{c}\text { Std. Error of the } \\
\text { Estimate }\end{array}$ & Durbin-Watson \\
\hline 1 & $.727^{\mathrm{a}}$ & .529 & .524 & 1.50367 & 2.002 \\
\hline
\end{tabular}

a. Predictors: (Constant), (kepuasan konsumen)X

b. Dependent (loyalitas merek)

Variable:Y

(Sumber : data angket yang diolah SPSS)

Pada tabel diatas diketahui nilai koefisien korelasi (R) 0,727 menunjukkan hubungan antara variabel bebas (kepuasan konsumen) dengan variabel terikat (Loyalitas Merek ) sebesar 72,7\%. Kemudian nilai koefisien determinasi (adjusted R square) sebesar 0,524, dari nilai tersebut menunjukkan bahwa variabel kepuasan konsumen (X), mempengaruhi loyalitas merek (Y) sebesar 0,524 atau $52,4 \%$. Sedangkan sisanya sebesar 0,476 atau 47,6\% dipengaruhi oleh variabel lain yang tidak digunakan dalam penelitan ini.

\section{Uji t Secara Parsial}

Uuji $\mathrm{T}$ digunakan untuk mengetahui pengaruh secara parsial dari variabel yaitu Kepuasan Konsumen (X) terhadap Loyalitas Merek (Y). dapat dilihat pada table berikut ini:

Table 4.24 Hasil Uji T

Coefficients $^{\mathrm{a}}$

\begin{tabular}{|c|c|c|c|c|c|c|c|c|c|c|}
\hline \multirow{2}{*}{\multicolumn{2}{|c|}{ Model }} & \multicolumn{2}{|c|}{$\begin{array}{l}\text { Unstandardize } \\
\text { d Coefficients }\end{array}$} & \multirow{2}{*}{\begin{tabular}{|c|}
$\begin{array}{c}\text { Standardiz } \\
\text { ed } \\
\text { Coefficient } \\
\text { s }\end{array}$ \\
Beta \\
\end{tabular}} & \multirow[b]{2}{*}{$\mathrm{T}$} & \multirow[b]{2}{*}{ Sig. } & \multicolumn{4}{|c|}{ Correlations } \\
\hline & & B & $\begin{array}{l}\text { Std. } \\
\text { Error }\end{array}$ & & & & $\begin{array}{l}\text { Zero- } \\
\text { order }\end{array}$ & Partial & $\mathrm{Pa}$ & \\
\hline \multirow{2}{*}{\multicolumn{2}{|c|}{\begin{tabular}{|ll}
1 & $($ Constan \\
& t) \\
& $X$ \\
\end{tabular}}} & $\begin{array}{r}11.54 \\
6\end{array}$ & 1.979 & & 2.452 & .016 & & & & \\
\hline & & 270 & .040 & .727 & $\begin{array}{r}10.49 \\
5\end{array}$ & .000 & .727 & .727 & & .727 \\
\hline
\end{tabular}

a. Dependent

Variable:Y

SumberDiolah dari hasil perhitungan SPSS 
Berdasar tabel diatas dapat diketahui bahwa nilai $t_{\text {hitung dengan tingkat }}$ probabilitas signifikan 0,000 (di bawah 0,05) sebesar 10,495. sedangkan $t_{\text {tabel }}$ dengan $\alpha=0.05$ dengan df pembilang $=\mathrm{k}$ $=1$ dan $\mathrm{df}$ penyebut $=\mathrm{n}-\mathrm{k}-1=100-1-1=98$ sehingga nilai $t_{\text {tabel }}$ sebesar 1,980 dengan demikian nilai $t_{\text {hitung }}>t_{\text {tabel }}(10,495>1,980)$. Jadi berdasar tingkat signifikannya dapat disimpulkan bahwa variabel kepuasan konsumen (X) memiliki pengaruh yang signifikan terhadap variabel loyalitas merek (Y). Sedangkan untuk mengetahui besarnya kontribusi yang diberikan variabel kepuasan konsumen (X) terhadap loyalitas merek (Y) dapat dilihat dari correlation partial $\left(r^{2}\right)=\left(0,727^{2}\right)=0,528$ yang berarti bahwa variabel kepuasan konsumen mampu menjelaskan variabel loyalitas merek sebesar 0,528 atau 52.8\%.

\section{PEMBAHASAN}

Berdasar hasil analisis linier sederhana maka diketahui nilai koefisien regresi variabel bebas tandanya positif. Hal ini menunjukkan hubungan yang searah antara variabel kepuasan konsumen (X) dengan Loyalitas merek (Y).

Berdasar hasil perhitungan menyatakan bahwa variabel kepuasan konsumen pada produk Pond's (X) mempunyai pengaruh yang signifikan sebesar 52,4\% terhadap variabel Loyalitas merek produk Pond's pada mahasiswi Fakultas Manajemen Universitas Negeri Surabaya, dan pengaruh yang signifikan sebesar 52,4\% tersebut memiliki hubungan yang dikategorikan sedang dari perubahan variabel loyalitas merek produk krim pemutih Pond's yang dipengaruhi oleh variabel kepuasan konsumen. dan sisanya $47,6 \%$ dipengaruhi oleh variabel lain diluar variabel yang digunakan dalam penelitian ini.

Item pernyataan yang paling dominan pengaruhnya dari variabel kepuasan konsumen produk Pond's terhadap loyalitas merek pada mahasiswi Fakultas Manajemen Universitas Negeri Surabaya adalah item pernyataan sub indikator harga dimana $40 \%$ responden menyatakan sangat setuju bahwa harga produk Pond's sesuaikan dengan kualitasnya. Selain pada sub indikator harga ditunjukkan juga respon konsumen yang besar pada manfaat produk yang menyatakan produk Pond's mengandung bahan untuk mencerahkan secara sempurna yaitu sebesar $65 \%$ responden menyatakan setuju.

Berdasar analisis yang telah dipaparkan diatas kepuasan yang tinggi dalam pengkonsumsian produk pemutih merek Pond's yang terjadi pada mahasiswi manajemen Fakultas Ekonomi Universitas Negeri Surabaya dipengaruhi oleh harga,kaulitas dan manfaat pada akhirnya akan membuat mahasiswi tersebut loyal pada merek Pond's.

\section{KESIMPULAN}

Berdasarkan pembahasan dan hasil analisis data yang dilakukan dalam penelitian ini dapat disimpulkan bahwa. Ada pengaruh antara kepuasan konsumen terhadap loyalitas merek pada Pemutih Merek Pond's pada Mahasiswi Manajemen Fakultas Ekonomi Universitas Negeri Surabaya. Item pernyataan yang paling dominan pengaruhnya dari variabel kepuasan konsumen produk Pond's terhadap loyalitas merek pada mahasiswi Fakultas Manajemen Universitas Negeri Surabaya. Harga merupakan item yang paling dominan mempengaruhi loyalitas merek pada Mahasiswi Fakultas Ekonomi Universitas Surabaya Hal ini disebabkan karena harga merupakan cerminan dari kualitas produk tersebut.

\section{SARAN}

Berdasarkan pembahasan dan hasil analisis data yang dilakukan dalam penelitian ini dapat disarankan beberapa hal sebagai berikut :

1. Bagi peneliti selanjutnya diharapkan untuk memperluas area sampel yang diteliti dan mengembangkan variabel diluar variabel dalam penelitian ini, karena masih ada $65,2 \%$ loyalitas 
merek yang dipengaruhi oleh variabel lain diluar variabel yang ada dalam penelitian ini.

2. Untuk item pernyataan yang menyatakan bahwa Pond's memberikan perubahan paling cepat 7 hari, pada peryataan ini responden cenderung menjawab ragu-ragu dibandingkan dengan pernyataan yang lainnya, disarankan untuk perusahaan lebih menjaga kepercayaan konsumen terhadap perusahaan bahwa produk Pond's ini benar-benar memberikan perubahan dengan cepat dengan cara perusahaan harus memberikan informasi yang lebih jelas lagi tahapantahapan apa saja yang harus dilakukan oleh konsumen sehingga dapat menghasilkan perubahan yang cepat. Dengan demikian terciptanya hubungan antara konsumen dengan produk yang memiliki manfaat yang dicari maka akan tercipta hubungan dan kesamaan emosi yang baik antara konsumen dengan merek, sehingga akan terjadi kenyamanan konsumen dalam menggunakan merek tersebut dan akhirnya konsumen terus menerus menggunakan merek tersebut.

\section{DAFTAR PUSTAKA}

Alma, Buchari. 2007. Manajemen Pemasaran dan Pemasaran Jasa.Bandung: Alfabeta

Kotler, Philip \& Keller, K.L.2005. Manajemen pemasaran (jilid 2). Bandung; Indeks

Kotler, Philip \& Keller, K.L.2007. Manajemen Pemasaran (ad 12). Indonesia: Indeks,

Santosa, P. B \& Ashari. 2005. Analisis Statistik dengan Microsoft Excel dan SPSS. Yogyakarta. ANDI

Sugiyono. 2006. Metode Penelitian Administrasi. Bandung :CV Alfabeta
Sugiyono. 2007. Metode Penelitian Kuantitatif Kualitatif Dan $R \& D$. Bandung : ALFABETA

Sugiyono. 2007. Statistika untuk Penelitian. Bandung :CV Alfabeta

www.vivawoman.net diakses 15

Oktober 2010 